\title{
Radiometric Surveys for Detection of Uranium in Dhofar Region, Sultanate of Oman
}

\author{
Narasimman Sundararajan ${ }^{1 *}$, Bernhard Pracejus, Salah Al- Khirbash, Talal K. Al-Hosni, \\ A. Ebrahimi, Ali Al Lazki ${ }^{2}$ and ${ }^{3}$ Musallam Al-Mushani
}

\author{
${ }^{1}$ Department of Earth Science, Sultan Qaboos University, P.O. Box 36, PC 123, Al-Khod, Muscat, \\ Sultanate of Oman; ${ }^{2}$ Petroleum Development of Oman (PDO), Muscat, Sultanate of Oman; \\ ${ }^{3}$ Ministry of Commerce and Industry, Muscat, Oman, *visvid12@squ.edu.om.
}

\begin{abstract}
The Proterozoic basement of the Dhofar region of the Sultanate of Oman might be considered as a potential source of Uranium mineralization like other Proterozoic basins of the world, which collectively contribute $30 \%-40 \%$ to the global production. Uranium exploration assumes great importance in this part of the world and therefore geochemical and geophysical exploration for Uranium was initiated. Initial, random sampling of the study area with Gamma ray spectrometry as well as in situ XRF (Xray Florescence) analysis indicated the presence of around 30-40 ppm of Uranium. Since Gamma ray spectrometry results in the calculation of the heat produced during radioactive decay of Potassium (K), Uranium (U) and Thorium (Th) within the rocks in the study area, measurements were acquired along eleven traverses of varying length from 100-250 m at a traverse interval of $20 \mathrm{~m}$ and sampling interval of $10 \mathrm{~m}$. Individual plots of the concentrations of radioelements such as $\mathrm{U}, \mathrm{K}$ and Th have shown favorable anomalous radioactive sources. Besides this, Uranium to Thorium (eU/eTh) and Uranium to Potassium (eU/K) ratio plots have been presented and the alteration zones associated with Uranium mineralization through all traverses have been identified. Further, the generated composite ternary image based on the combination of K, Th and U from Gamma ray spectrometry determines different relative amounts of radioelements and paves the way for deciphering the level of radioactivity in the study area. However, there seems to be no presence of strong Uranium anomalies in the near surface of the limited study area. As the study area is heavily faulted, the depth to concealed subsurface fault structures is estimated to be around $64 \mathrm{~m}$ based on Hartley spectral analysis of total magnetic anomaly (line-6).
\end{abstract}

Keywords: Gamma ray spectrometry; XRF analysis; Uranium; Potassium; Thorium.

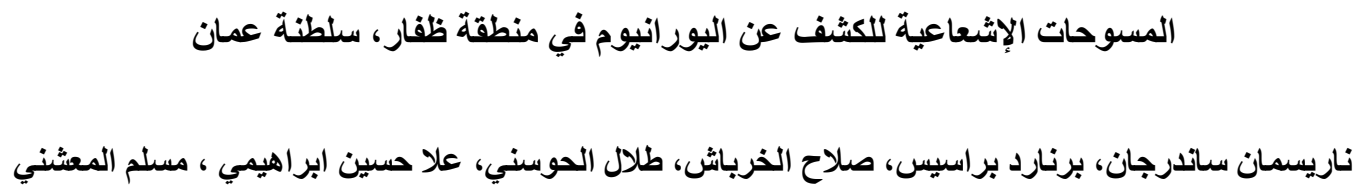

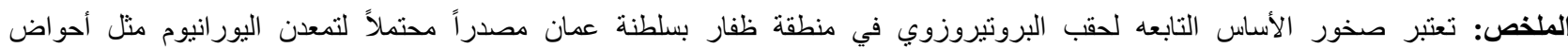

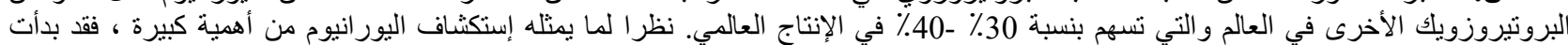

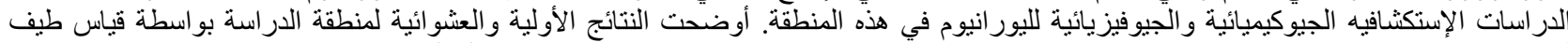

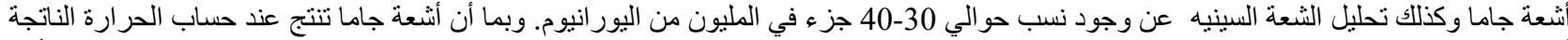

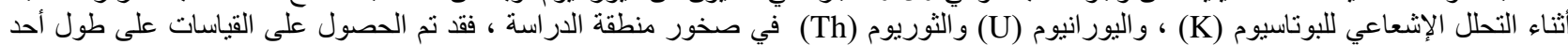

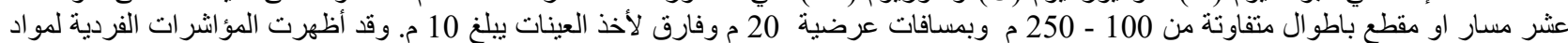

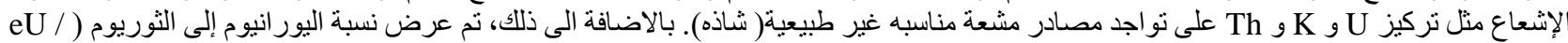

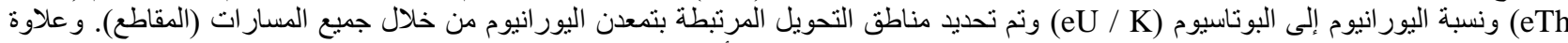

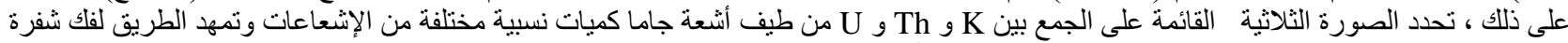

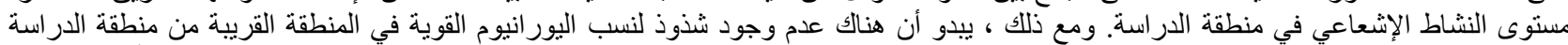

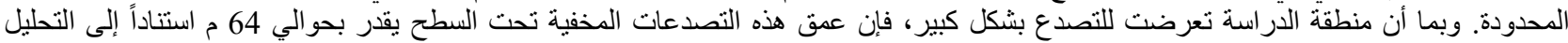

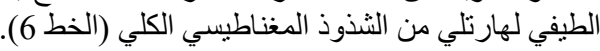
الكلمات المفتاحية: أشعة جاما، تحليل الأشعة السينية، يور انيوم، ظفار، عمان. 


\section{RADIOMETRIC SURVEYS FOR DETECTION OF URANIUM}

\section{Introduction}

$\mathbf{U}$ ranium is a strategically important mineral having wide applications in the field of energy (electricity) and other industrial research and development ( $R$ and $\mathrm{D}$ ) sectors. This futuristic resource is very important for developing countries, hence the government of Oman is keen to evaluate its resources. The Proterozoic basement of the Dhofar region of Oman might be a potential source of Uranium mineralization in the light of the global production of Uranium (30\%-40\%) coming from Proterozoic basins, especially from Canada, Australia and Kazakhstan. Spectrometry is a well-established analytical technique that has been widely used in $\mathrm{R}$ and $\mathrm{D}$ for elemental composition analysis. A relatively recent development has been the availability of sophisticated digital instrumentation, which can be transported to field sites and used for both direct and in situ non-destructive analysis of samples. Their non-destructive analysis, multi element capability, speed of operation and access to valuable samples are further major advantages of field-portable spectrometers [1]. Gamma ray spectrometry is a surveying technique that allows the calculation of the heat produced during radioactive decay of Uranium (U), Thorium(Th) and Potassium(K) within rocks [2].

Many natural elements have radioactive isotopes, but only $\mathrm{U}$, Th and $\mathrm{K}$ decay series produce sufficient energy and intensity to be measured by $\gamma$-ray spectrometry. These decay series have the greatest intensity for the energy ranges of 1.37-1.57 MeV for Potassium (40K), 1.66-1.86 MeV for Uranium (238U) and 2.41-2.81 MeV for Thorium (232Th) [2]. Gamma rays are used to determine the quantities of these elements in rocks; alpha and beta components of decay produce much more heat than Gamma rays, especially so the alpha decay of Uranium [3].

Spectrometric surveying will allow better constraint of resources estimation and help to target drilling. Airborne Gamma ray spectrometry is a major geologic mapping strategy in different environments, such as mineral, environmental, hydrocarbon and even ground water investigations [4-6]. In geothermal investigation, Gamma ray spectroscopy could be used to determine radiogenic heat producing rocks that are often targets for geothermal exploration and production [7]. Geochemical and geophysical surveys in the search for metallic ores [8] have been carried out around the world with the help of Gamma ray spectrometry. An in-situ field Gamma ray study with a portable Gamma ray spectrometer using a sodium iodide detector was carried out by Grasty [9] to analyze lithological variations by assessing the concentration of radioelements.

In our investigation, a BGO Super RS-230 spectrometer was used to measure the concentrations of these radioactive elements in the Dhofar region of the Sultanate of Oman. The study was also substantiated by random sampling of both Gamma ray spectrometry and by Geochemical analysis of samples acquired by XRF from the study area. The results of Gamma ray spectrometry and XRF were correlated to highlight the salient features of the entire investigation.

\section{Uranium Occurrence}

The major types of Uranium deposits are grouped according to their respective geological setting [10-13]. Unconformity-related deposits occur in the immediate vicinity of major unconformities separating igneous basement and overlying clastic sediments. Metasediments near the area are usually faulted and brecciated and are the locus of the main mineralization. Igneous environments not only include intrusive rocks per se, but also the vein deposits (graniterelated and stock works), pegmatites containing rare metals ( $\mathrm{Sn}, \mathrm{Ta}, \mathrm{Nb}, \mathrm{Li}$, and REEs), volcanic and caldera-related deposits, as well as hematite breccia complex deposits (associated with a near surface explosive events involving boiling processes).

In metamorphic deposits, the Uranium enrichment can be derived and concentrate in metamorphosed rock. However, metasomatic processes (e.g., Na metasomatism) lead to a re-distribution of Uranium via leaching, transport, and mineralization in the form of disseminations within structurally deformed rocks (Precambrian shields). With the exception of phosphorites (marine, and of continental-shelf origin), sedimentary Uranium deposits show the significance of carbon (coal and hydrocarbons) in capturing Uranium by absorbing it on lignite, organic matter in black shales (also carbonaceous pyritic shales) and sandstone deposits (medium to coarse-grained continental fluvial or marginal marine sediments under reducing conditions and occasionally quite $\mathrm{C}$-rich; categorized into roll-front, tabular, basal channel, and tectonic/ lithologic deposits). While the geological environment of some Archaean to early Palaeoproterozoic quartz pebble conglomerate deposits with detrital uraninite could also be classified as metamorphic environments, they also clearly indicate reducing conditions (anoxic atmosphere, prevalence of hydrocarbons at least during overprinting). In addition, hydrocarbons occasionally also enrich Uranium.

Two-thirds of the world's production of Uranium comes from Kazakhstan, Canada and Australia, and mostly comes from Proterozoic rocks [14]. The Athabasca basin (Canada) accounts for 30\% of the world's high grade Uranium production [15]. The surface of the basin consists of mainly sandstone sediment varying from 100 to 1000 meters in depth. The Uranium ore is mostly found at the base of this sandstone, at the point where it meets the basement [15]. In Australia, Queensland is the largest producer of Uranium [16]. Kazakhstan has also been an important source of Uranium for more than 50 years. New investigations to evaluate Uranium contents are occurring in India, Uzbekistan and many other countries around the world. Jordan is the only country in the Middle East that has a confirmed availability of Uranium [17]. 


\section{N. SUNDARARAJAN ET AL}

The history of Uranium exploration began during early 1980s in the Sultanate of Oman, wherein [18-20] a number of target areas have been identified. In our study, a couple of sites were selected on the basis of prevailing radiation which prompted further investigation using geophysical and geochemical methods. Accordingly, the Gamma ray spectrometry investigation was carried out to trace the Uranium concentration in addition to in situ XRF measurements. Subsequently, a detailed story based on VLF-EM survey has been carried out. According to Forbes et al. [21], in southwestern Oman (some $300 \mathrm{~km}$ west of our site), there are indications of high radiation in oil well logs which intersect the shales of the Andhur formation. The carbon content of these shales could have acted as a preconcentrating medium for Uranium, while faults intersecting such formations then presented the pathways for migrating fluids [21].

\section{Gamma Ray Spectrometry}

The most obvious technique to explore Uranium deposits is the radiometric method, as it directly records the decay of the isotopes of these elements. All rocks and soils are naturally radioactive, containing various proportions of those radioactive elements [22]. Their natural decay produces a variety of radiation (alpha, beta, and Gamma) at specific energy levels. Only Gamma ray radiation has adequate energy to be useful for geological mapping and exploration [22]. Thus, Gamma ray spectrometry aids in measuring concentrations of the individual radioactive elements $\mathrm{U}$, Th and $\mathrm{K}$ as the basis for mapping rocks and soils by virtue of their characteristic radioactivity signatures $[23,24]$.

The spectrometry data processing techniques mostly are qualitative, illustrating radioelements (U, Th and K) in the form of maps and related ratios to decipher the potential of radioactive regions. These maps of the elements viz. $\mathrm{U}$, $\mathrm{Th}$ and $\mathrm{K}$ show the individual concentrations of their levels in order to understand the activity ratio of the three radioelements [2 and 25]. Maps of the ratio of Uranium/Thorium (eU/eTh) and Uranium/Potassium (eU/K) represent the alteration zones associated with Uranium mineralization and other reducing environments which may be favorable indications for Uranium mineralization. Further, a high Uranium and eU/Th ratio can often indicate that an area has undergone multiple phases of remobilization and concentration [26 and 27]. The composite ternary image represents clearly different relative amounts of the radioelements (U, Th and K) in three different colors, wherein the intensity of each color is proportional to a specific concentration. The concentration of different radioelements varies among different rock types and can be estimated through a Gamma ray spectrometer measurement and mapping of the rocks. When the normal radioelement signature of the rocks is disrupted by a mineralized system, corresponding radioelement anomalies may provide direct exploration guidance [7].

\section{Geology of the Study Area}

The study area spreads over an area of $0.35 \mathrm{~km}^{2}$ (Dhofar region) and encompasses the UTM of Easting 757580.61 to 758112.08 and Northing 1868379.43 to 1869328.01 (Figure 1(a)). In this study, the focus is on the relatively young sub-horizontal layers of Tertiary micritic (EOzl) and lacustrine (Oaq) limestones including calcretes (surficial deposits) that are cross-cut by mineralised fault systems (veins). Geological map and vertical profile (the green arrow indicates the approximate position of the investigated site (Figure 1(b) and Table 1); the yellow line on the map corresponds to the location of the profile) in Figure 1(b), modified after the geological map of Oman W of Salalah (courtesy Ministry of Commerce and Industry, 2013).

Table 1. Overview of the geological rock units of the study area

\begin{tabular}{c|c|c|c|l}
\hline Label & Age (ma) & Stratigraphic Unit & Formation & \multicolumn{1}{|l}{ Description } \\
\hline Qcx-z & 24 & Quaternary & $/$ & slope colluvium \\
\hline EOzl & 92 & Tertiary & Zalumah & micritic limestones \\
\hline Oaq & 94 & Tertiary & Ashawq & lacustrine limestones \\
\hline Eay & 105 & Tertiary & Aydim & bioclastic limestones \\
\hline Edm2-3 & 110 & Tertiary & Dammam & bioclastic limestones \\
\hline Edm1 & 113 & Tertiary & Andhur & shale and intercalated limestones \\
\hline Ers & 120 & Tertiary & Rus & chalky dolomitic limestone and marl \\
\hline
\end{tabular}




\section{RADIOMETRIC SURVEYS FOR DETECTION OF URANIUM}

The area is heavily faulted (striking NE-SW, Figure 1(b)). Some of these faults have already been identified as the places of Uranium enrichment [18-20]. Since many of the limestone samples of the area have U levels below the detection limit of our equipment (portable XRF: $<1 \mathrm{ppm}$ ), we can rule out a general unfocussed disseminated Uranium enrichment of the rocks. Rather, the fault systems must have acted as fluid conduits for circulating waters scooping up Uranium from deeper formations and carrying it to higher levels along the fault plane and also distributing it near the surface. Possible sources for the observed U anomalies are: the Crystalline Proterozoic basement of the ArabianNubian Shield outcropping west of Salalah [27], igneous continental basement and carbonaceous shales, which appear in the underlying Andhur formation (Edm1; Figure 1(b) and Table 1) and which occur much higher up in the section (several kilometers above the basement, although precise information regarding depth is not available for this location).

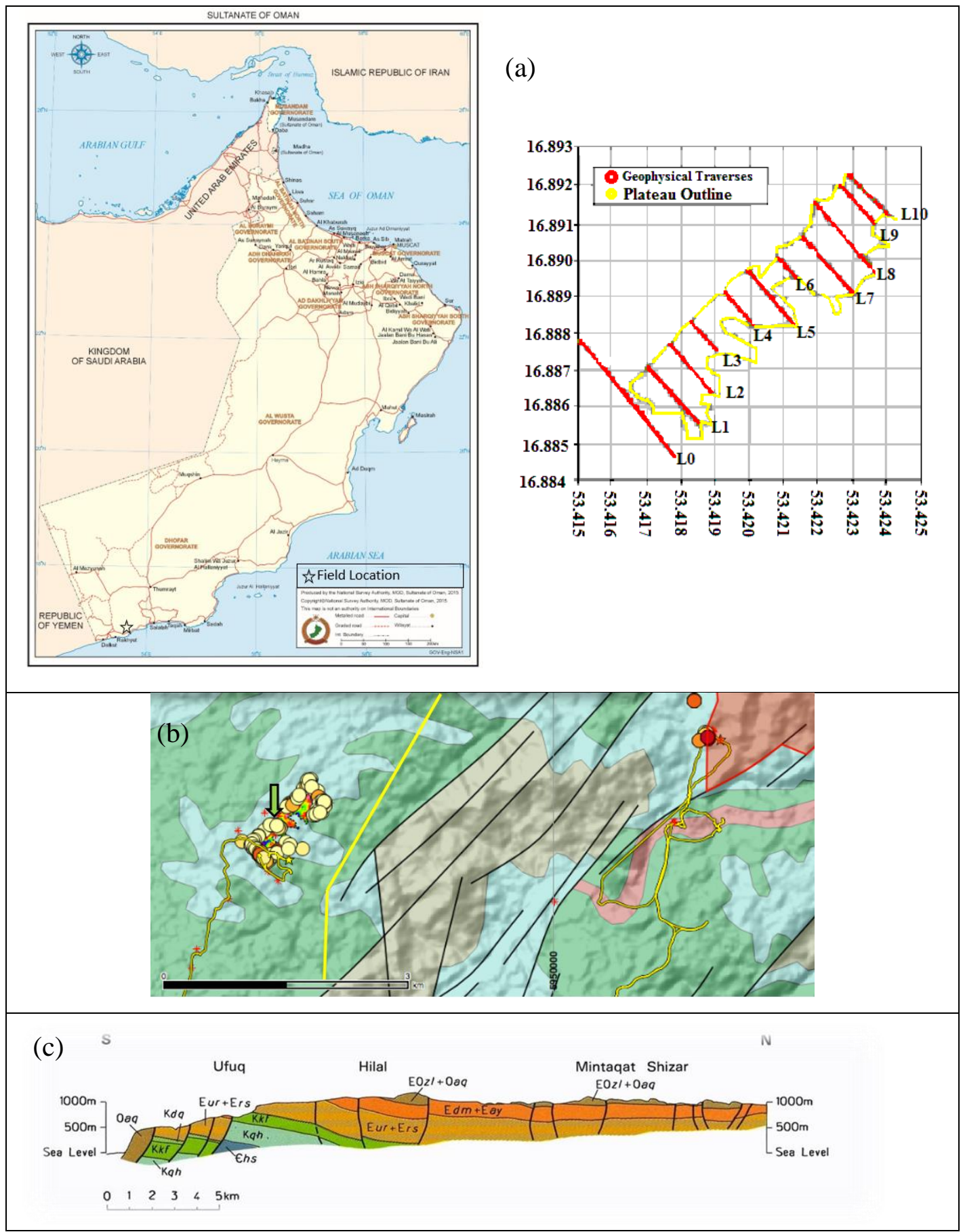

Figure 1. (a) Location of study area and geophysical traverses. The map was produced with SimpleDEMViewer for Mac (version 4.4.9), ASTER GDEM data (product of METI and NASA), QGIS (version 2.0.1-Dufour) under GNU General Public License (b) Geological map (the green arrow indicates the approximate position of the investigated site and the yellow line corresponds to the location of traverses (c) Geological profile (S-N) near the investigation site [28]. 


\section{N. SUNDARARAJAN ET AL}

\section{Data Acquisition}

Measurements were recorded along 11 traverses, $20 \mathrm{~m}$ apart and at station interval of $10 \mathrm{~m}$. The number of measurements along each line varied as the area is irregular in shape. The Gamma ray spectrometry recorded close to, or slightly higher than, the background level along all these traverses (Figure 1(c)). Total magnetic field was also recorded along all these traverses at the same measurement interval and the results are available in the literature [28]. It may be noted that there were isolated elevated readings of uranium concentrations in the range 30-40 ppm on random sampling near to the study area. The recorded data, viz., radioelement dose ( $\mathrm{nGy} / \mathrm{h}), \mathrm{U}$, Th and $\mathrm{K}$, are displayed as contour images in order to decipher the distribution of these elements in the study area. Figure 2 represents the radioelement dose while Figures 3a, $3 \mathrm{~b}$ and $3 \mathrm{c}$ illustrate the concentrations of $\mathrm{U}$, Th and K respectively.

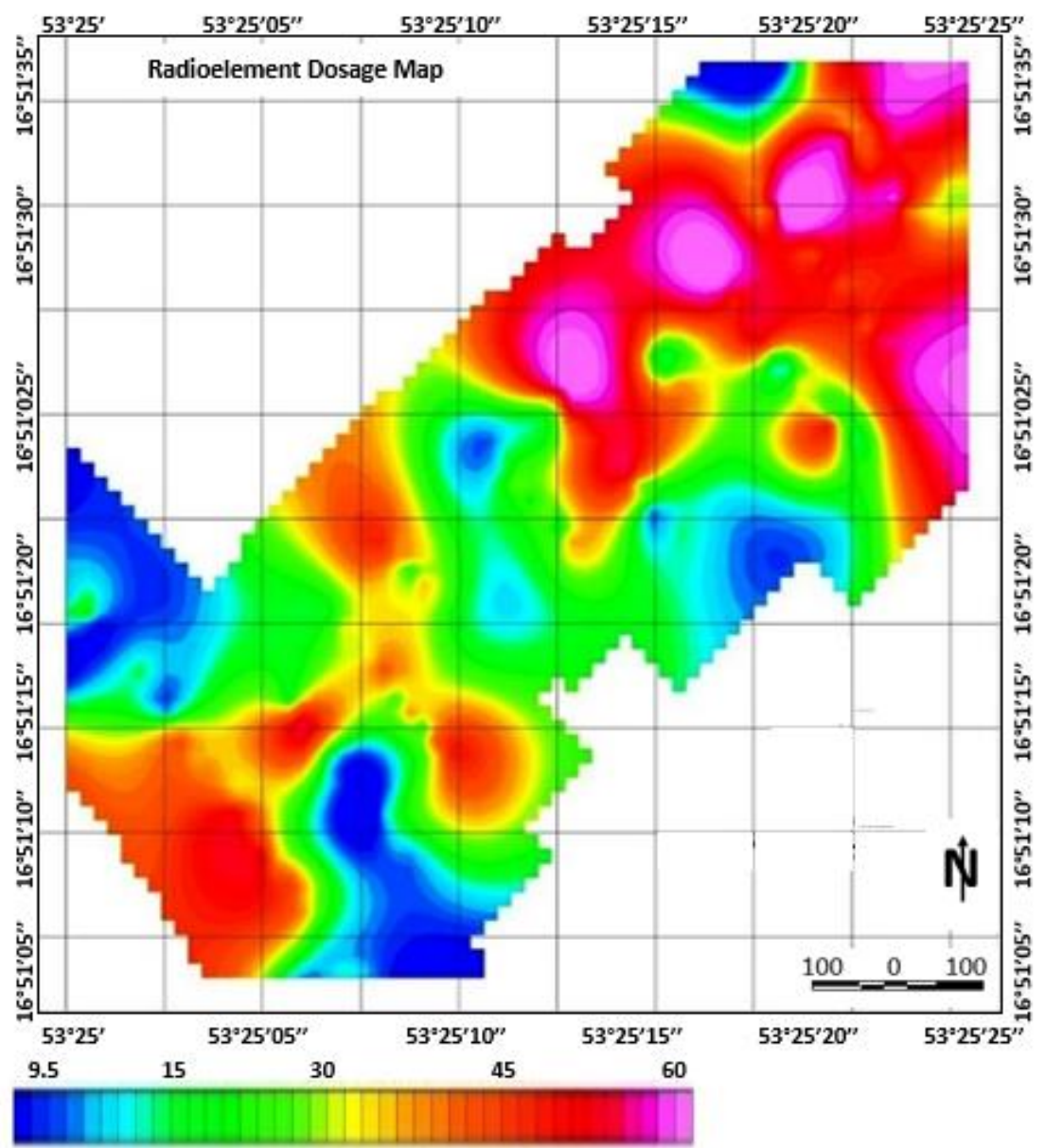

Figure 2. Contour image of radioelement dose (nGy/h) recorded by Gamma ray spectrometer.

The ratio maps of (eU/eTh) and (eU/K) are shown in Figure 4. In addition, in situ geochemical analysis in the field as well as of rock samples analyzed in the laboratory was carried out by a handheld Niton XL3t 950 XRF Analyzer (Thermo Scientific), used in geochemical survey to directly examine anomalies indicated out by a Gamma ray spectrometer. The device is equipped with an SDD GOLDD+ Detector and an Ag-anode X-ray tube; the excitation voltage is $50 \mathrm{kV}$ (200 mA, 2 Watt). The instrument auto calibrates on activation. Figures $5 \mathrm{a}$ and $5 \mathrm{~b}$ represent the composite ternary image which was generated by combining three sets of the data pertaining to $\mathrm{K}$, Th and $\mathrm{U}$ from Gamma ray spectroscopy and XRF analysis respectively. The equivalent Uranium ratio composite (eU, eU/eTh and $\mathrm{eU} / \mathrm{K})$ image is shown in Figure 6.

As reported in the geology section above, the study area is heavily faulted. The Hartley spectral analysis of total magnetic anomaly of line-VI is presented to decipher the depth to the concealed fault. The method is briefly described hereunder.

The Hartley transform of the total magnetic anomaly (T(x)) can be defined as [29]

$$
H(w)=\int_{-\infty}^{+\infty} T(x) \operatorname{cas}(w x) d x
$$




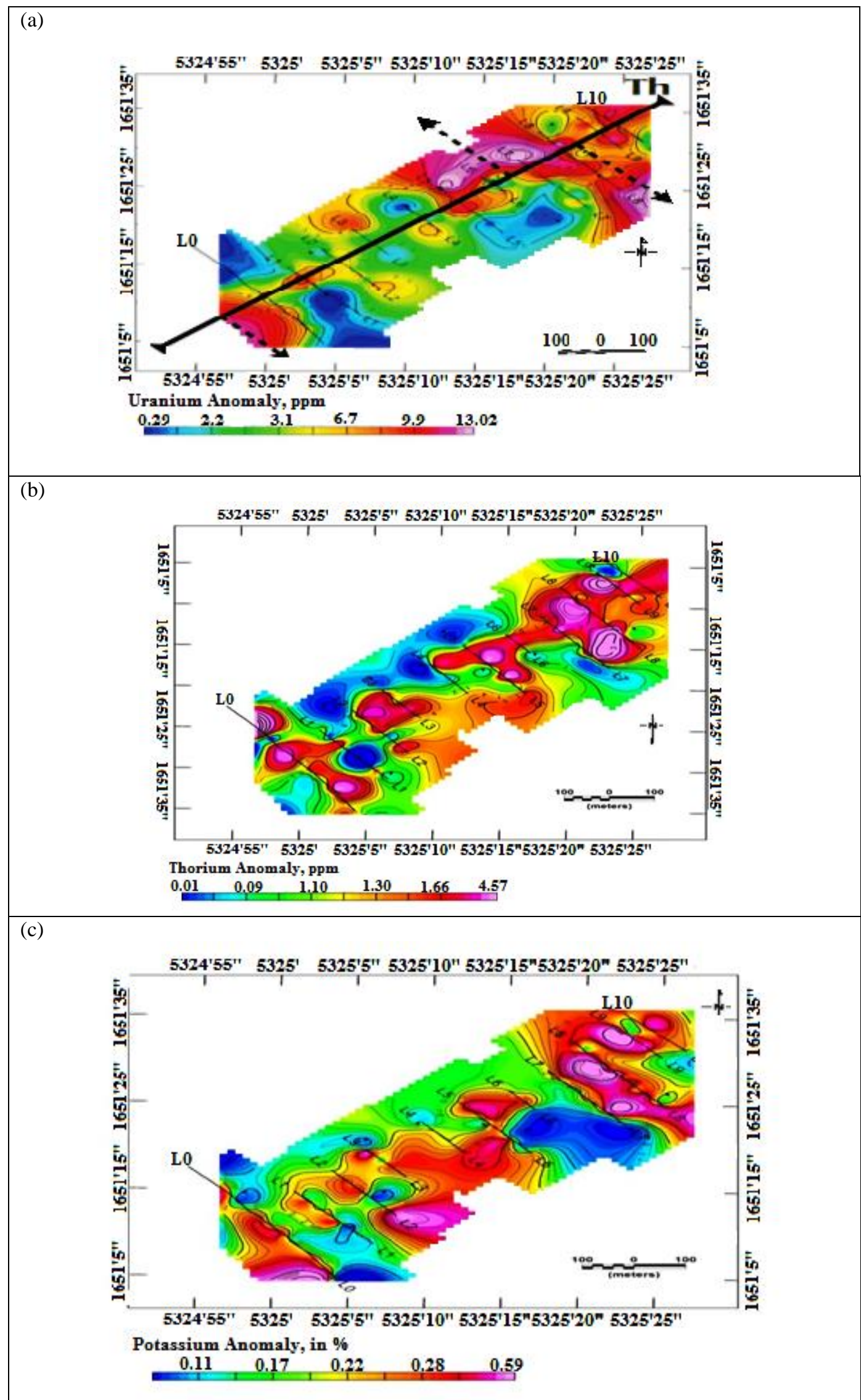

Figure 3. Contour image of concentration in ppm of (a) Uranium (b) Thorium and (c) Potassium recorded by Gamma ray spectrometer. 


\section{N. SUNDARARAJAN ET AL}

where

is a 45 degrees phase shifted sine wave.

$$
\operatorname{cas}(w x)=\cos (w x)+\sin (w x)
$$

$$
\mathrm{H}(w)=\mathrm{E}(w)+O(w)
$$

where $\mathrm{E}(w)$ and $O(w)$ are the even and odd components of the Hartley transform $\mathrm{H}(w)$.

The amplitude spectrum is given by

$$
\mathrm{A}(w)=\sqrt{(\mathrm{E}(w) * \mathrm{E}(w)+\mathrm{O}(w) * \mathrm{O}(w)}
$$

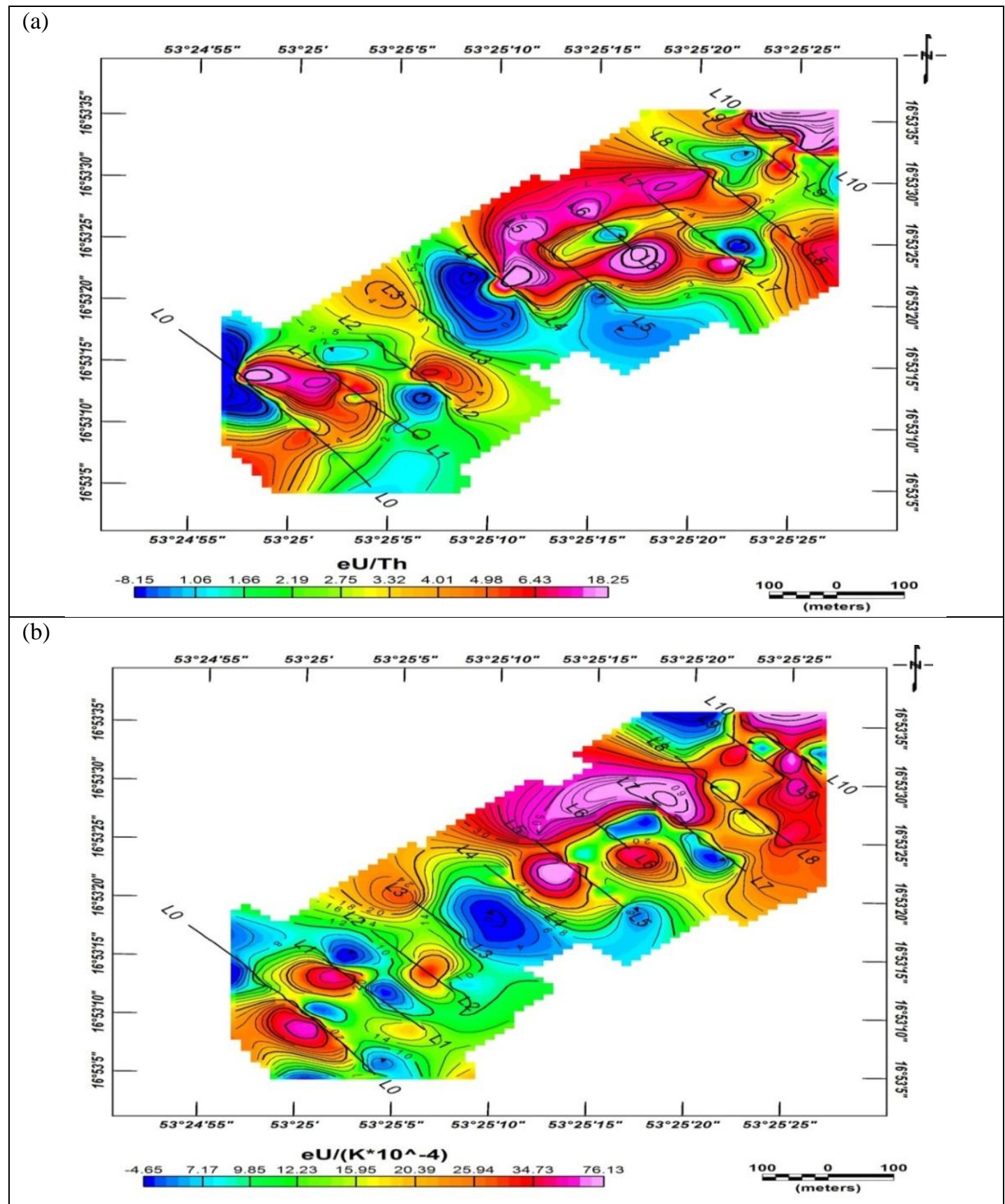

Figure 4. Contour image of the ratio of (eU/Th) and (eU/K) expressed in ppm. 
The Hartley transform is identical to the well-known 1-D Fourier transform and yields the same amplitude spectrum as that of Fourier amplitude, but with a 45 degree phase shifted spectrum. In the case of traverse VI, the Hartley spectra [30] was computed and shown in Figure 7, which represents the wave number versus the log amplitude spectra of the total magnetic anomaly in which the slope of the least square fitted straight line results approximate depth.

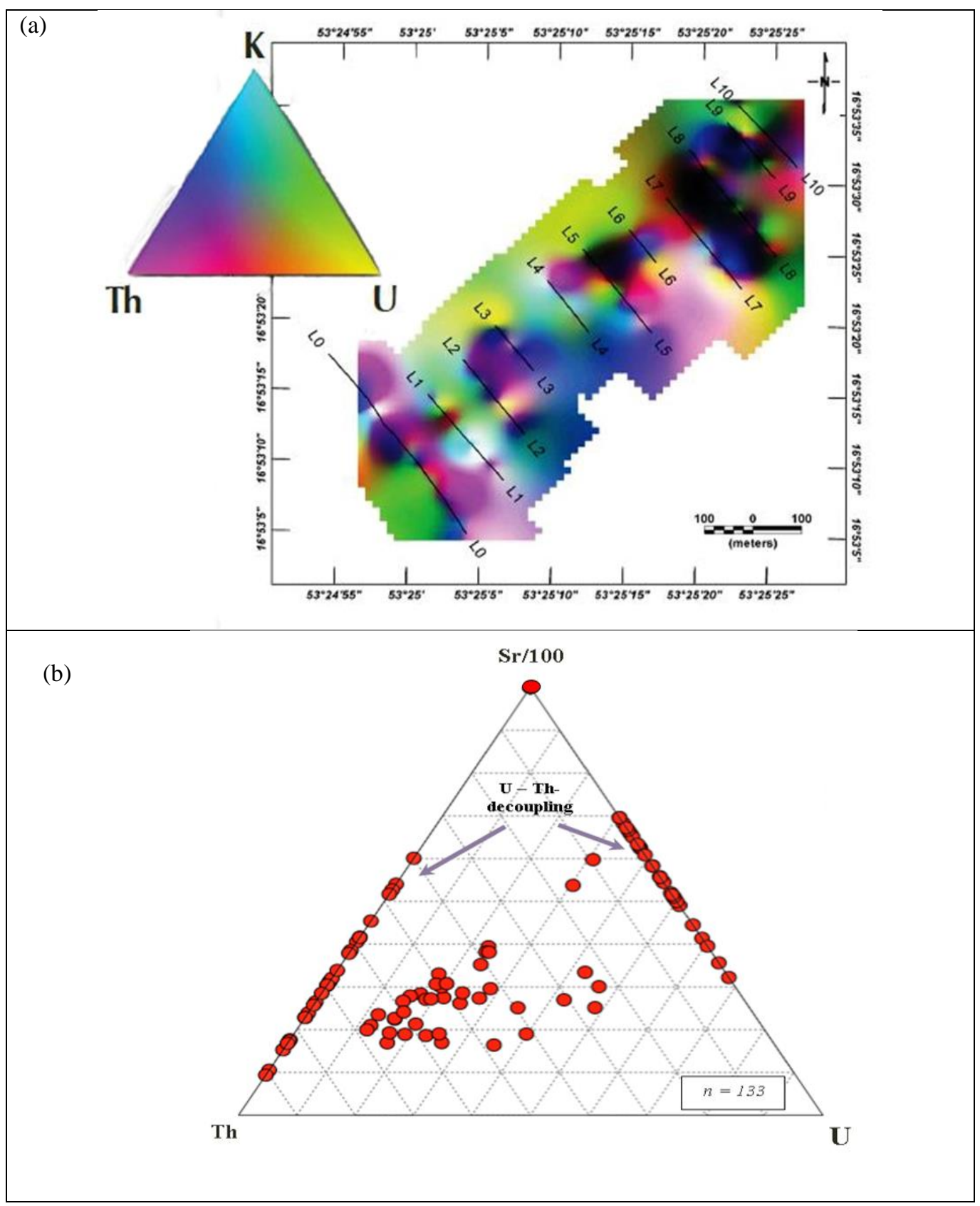

Figure 5. Composite ternary image derived from (a) Gamma ray spectrometry and (b) XRF analysis.

\section{Results and Discussion}

The abundance of the examined radioelements $\mathrm{U}$, Th and $\mathrm{K}$ varies significantly with the lithology of the study area (Figure 3a, b and c) reflecting the presence of rocks such as lacustrine limestones, bioclastic limestones, micritic limestones, shale units with intercalated limestones and chalky dolomitic limestones and marls. Further, it may be noticed from Figure 3a that an elevated Uranium concentration exists along traverses L5 to L8 and also in traverse L10. The ratio of equivalent Uranium to Thorium (Figure 4a) and the ratio of eU/K (Figure 4b) marginally differ in the concentration of Uranium wherein elevated levels of Uranium are visible along traverses L0, L4-L7 and L10 in Figure 4a, whereas traverses L0, L5-L7 and L10 show similar elevated levels of U in Figure 4b. The composite ternary image 


\section{N. SUNDARARAJAN ET AL}

from Gamma ray spectroscopy (Figure 5a) simultaneously displays the radioelement concentrations, although a spatial shift of Uranium away from an inferred line of the observed Th anomalies exists since $\mathrm{U}$ is more mobile than Th. Similarly, a ternary diagram of $\mathrm{Th}$ and Sr shows a clear separation between $\mathrm{U}$ and $\mathrm{Th}$ in the geochemical analysis (Figure 5b). In addition, the composite ternary image of the equivalent Uranium map (Figure 6) substantiates such a separation of the observations seen from Figure 5a and 5b. However, the results do not reveal any strong Uranium anomalies. On the other hand, the spectral analysis of the total magnetic anomaly pertaining to line -VI indicates the depth to the subsurface fault as being around $60 \mathrm{~m}$, and this cover of the fault may explain the difficulty in locating a distinctive radiogenic anomaly.

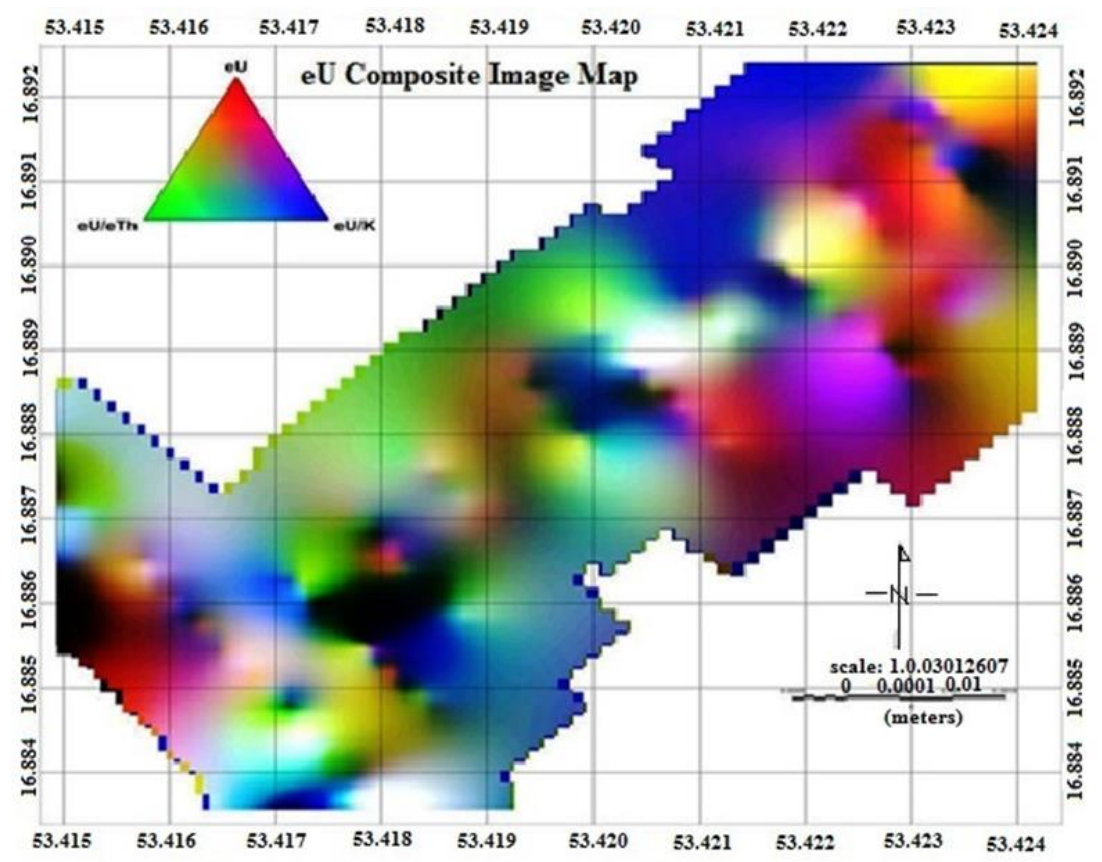

Figure 6. Equivalent Uranium concentration (ppm) image map.

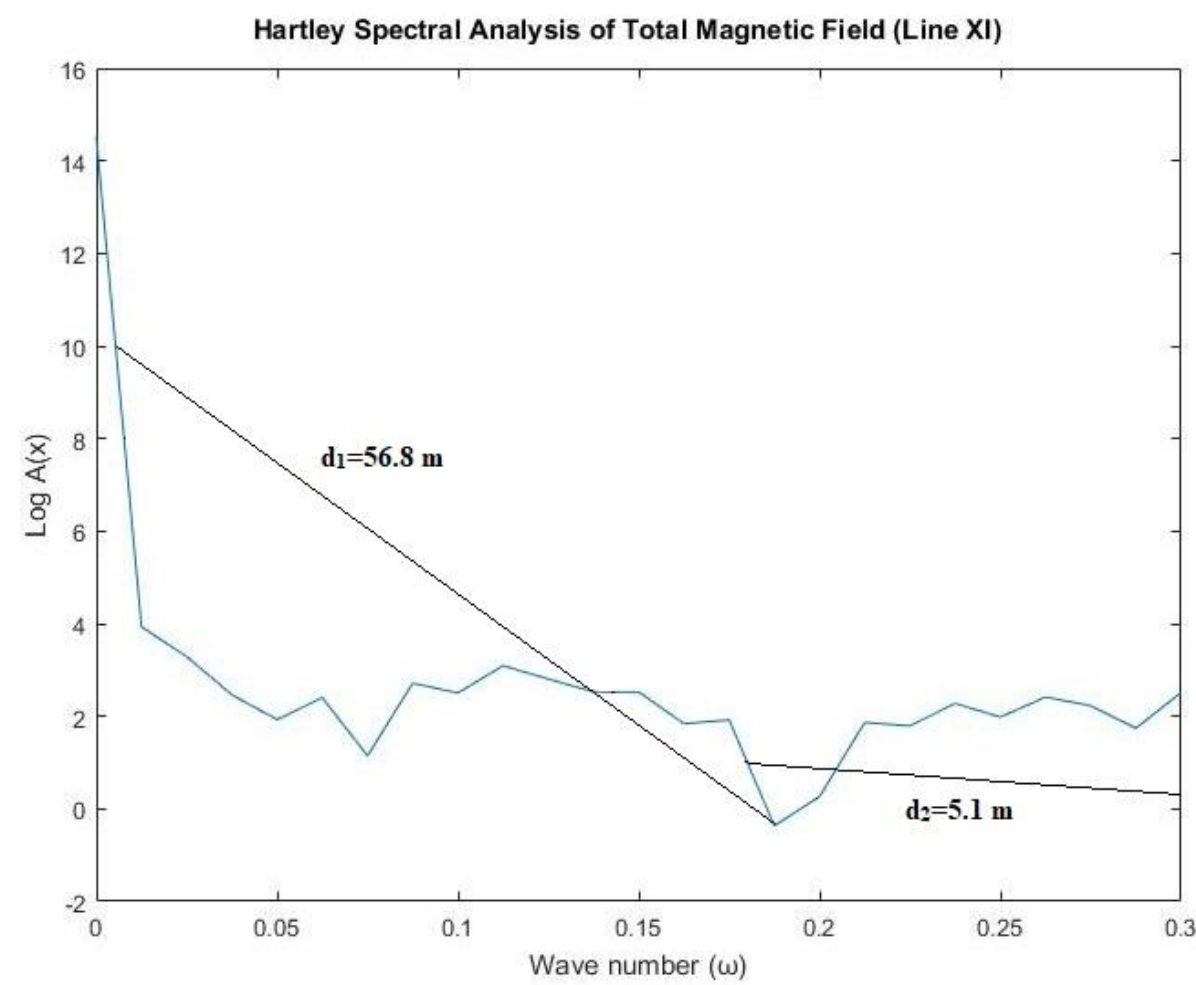

Figure 7. Hartley spectral analysis of total magnetic anomaly of line-VI indicating the depth to subsurface fault. 


\section{RADIOMETRIC SURVEYS FOR DETECTION OF URANIUM}

\section{Conclusion}

The Gamma ray spectroscopic measurements recorded in the study area have shown the concentrations of radioelements particularly Uranium as being only close to ambient noise values, and sporadically a little more in the range 30-40 ppm. However, within this range, a spatial shift of Uranium away from an inferred line of the observed Th anomalies was observed since Uranium is more mobile than Thorium. This sort of separation between Uranium and Thorium is further supported by the geochemistry. The combined geophysical and geochemical study in an area of less than one third square $\mathrm{km}$ did not reveal any strong uranium anomalies but it does not rule out the possibility of Uranium mineralization sites elsewhere in the region. An airborne Gamma ray spectroscopic study may yield a clearer picture of the Dhofar region in the Sultanate of Oman.

\section{Acknowledgement}

The authors wish to record their sincere thanks to Sultan Qaboos University for the strategic grant (SR/SCI/ETHS/12/02) to support this investigation. The reviewers are acknowledged for their constructive review and many useful suggestions to improve the manuscript.

\section{References}

1. Povinec, P. Commanducci, J., and Levy-Palomo, I. IAEA-MEL's underground counting laboratory (CAVE) for the analysis of radionuclides in the environment at very low-levels. Journal of Radioanalytical and Nuclear Chemistry, 2005, 263(2), 441-445.

2. IAEA. Guidelines for radioelement mapping using Gamma ray spectrometry data, IAEA-TECDOC-1363, Vienna, Austria. 2003, 97.

3. Rybach, L. Radioactive heat production in rocks and its relation to other petrophysical parameters. Pure and Applied Geophysics, 1976, 114(2), 309-317.

4. Ward, S.H. Gamma ray spectrometry in geologic mapping and Uranium exploration. Economic Geology, 1981, 75, 840-849.

5. Crowley, J.K., Brickey, D.W. and Rowan, L.C. Airborne imaging spectrometer data of the Ruby Mountains, Montana: mineral discrimination using relative absorption band-depth images. Remote Sensing of Environment, 1989, 29(2), 121-134.

6. Schlapfer, D. and Richter, R. Geo-atmospheric processing of airborne imaging spectrometry data. Part 1: parametric orthorectification. International Journal of Remote Sensing, 2002, 23(13), 2609-2630.

7. McCay, A.T. Harley, T.L., Younger, P.L., Sanderson, D.C., and Cresswell, A.J. Gamma ray Spectrometry in Geothermal Exploration: State of the Art Techniques. Energies, 2014, 7(8), 4757-4780.

8. Grasty, R.L. Gamma ray spectrometric methods in Uranium exploration- Theory and operational procedures in Geophysics and geochemistry in the search for metallic ores, Geological Survey of Canada Economic Geology,1979, Report 31, 147-161.

9. Grasty, R. Spectral component analysis applied to portable Gamma ray spectrometry. ASEG Extended Abstracts, 2001, 1, 1-4.

10. Toens, P. and Hambleton-Jones, B. Definition and classification of surficial Uranium deposits, 1984.

11. Adler, H. Concepts of Uranium-ore formation in reducing environments in sandstones and other sediments. Formation of Uranium ore deposits, 1974, 141-168.

12. Poty, B., Leroy, J., Cathelineau, M., Cuney, M., Friedrich, M., Lespinasse, M. and Turpin, L. Uranium deposits spatially related to granites in the French part of the Hercynian orogen, 1986, (No. IAEA-TECDOC-361).

13. Fralick, P.W. and Miall, A.D. Sedimentology of the Lower Huronian Supergroup (Early Proterozoic), Elliot Lake area, Ontario, Canada. Sedimentary Geology. 1989, 63(1), 127-153.

14. Guang, Y. and Wenjie, H. The status quo of China's nuclear power and the Uranium gap solution. Energy Policy, 2010, 38(2), 966-975.

15. Jefferson, C., Thomas, D., Gandhi, S., Ramaekers, P., Delaney, G., Brisbin, D. and Olson, R. Unconformityassociated Uranium deposits of the Athabasca Basin, Saskatchewan and Alberta. BULLETIN-GEOLOGICAL SURVEY OF CANADA. 2007, 588, 23.

16. Brooks, J. Uranium exploration in Queensland. Geological Survey of Queensland. 1972, Report 69, 6-8.

17. Abusini, M., Al-Ayasreh, K. and Al-Jundi, J. Determination of Uranium, Thorium and Potassium activity concentrations in soil cores in Araba valley, Jordan. Radiation protection dosimetry, 2008, 128(2), 213-216.

18. Quidwai, H.A. Wadi Gharbatan Uranium prospect - Final report. MPM unpublished report, 1981.

19. Quidwai, H.A. and Khalifa, M.I. Ground follow-up of the airborne radiometric anomalies in south western Dhofar, Sultanate of Oman: Ministry of Petroleum and Minerals, unpublished report, 1982. 


\section{N. SUNDARARAJAN ET AL}

20. BRGM. Geological study of the mineral occurrence of the central part of the Northern Oman mountains. BRGM/Oman. Unpublished report,1984, 2-28.

21. Forbes, G., Jansen, H. and Schreurs, J. Lexicon of Oman Subsurface Stratigraphy (GeoArabia Special Publication 5). Gulf PetroLink, Bahrain, 2010.

22. Telford, W. and Geldart, L. Sheriff. RE. Applied Geophysics. Cambridge University Press, 1990, 770 (157), 315329.

23. Guagliardi, I., Buttafuoco, G., Apollaro, C., Bloise, A., De Rosa, R. and Cicchella, D. Using Gamm ray spectrometry and geostatistics for assessing geochemical behaviour of radioactive elements in the Lese catchment (southern Italy). International Journal of Environmental Research, 2013, 7(3), 645-658.

24. Lovborg, L. Botter-Jensen, L., Kirkegaard, P., and Christiansen, E. Monitoring of natural soil radioactivity with portable Gamma ray spectrometers. Nuclear Instruments and Methods, 1979, 167(2), 341-348.

25. Wilford, J. Airborne Gamma ray spectrometry. Cooperative Research Centre for Landscape Envirionments and Mineral Exploration, Commonwealth Scientific and Indusctrial Research Organization, Bertley, WA, Australia. Open File Rep, 2002, 144, 46-52.

26. Adams, J.A. and Weaver, C.E. Thorium-to-Uranium ratios as indicators of sedimentary processes: example of concept of geochemical facies. AAPG Bulletin, 1958, 42(2), 387-430.

27. Mercolli, I. Briner, A.P., Frei, R., Schonberg, R., Nagler, T.F., Kramers, J., and Peters, T. Lithostratigraphy and geochronology of the Neoproterozoic crystalline basement of Salalah, Dhofar, Sultanate of Oman. Precambrian Research, 2006, 145(3), 182-206.

28. Béchennec, F. Le Métour, J. Platel, J.P. Roger, J. Geological Map of the Sultanate of Oman (1:250000, GIS Version), Explanatory Notes. Ministry of Petroleum and Minerals, Directorate General of Minerals, Sultanate of Oman, Muscat, 1993.

29. Sundararajan N, Pracejus B, Al- Khirbash S, Al- Hosni TK, Ebrahimy A. and M. Al-mushani. Magnetic Mapping for Delineating Structures Favorable to Uranium Mineralization in Dhofar Region, Sultanate of Oman. International Journal of Earth and Environmental Science, 2017, 127, 2-9.

30. Bracewell, R.N. Fourier transform and its applications, McGraw Hill Book Co, 1986.

31. Sundararajan N, Al-Garni MA, Ramabrahmam G. and Srinivas Y. A real spectral analysis of the deformation of a homogeneous electric field over a thin bed - a Hartley transform approach. Geophysical Prospecting, 2007, 55, 901-910.

Received 16 November 2017

Accepted 23 September 2018 